\title{
FAMILY AS A FACTOR OF PRESCHOOLCHILD`S DETERMINATION OF PSYCHOLOGICAL GENDER
}

\section{СІМ'Я ЯК ЧИННИК СТАНОВЛЕННЯ ПСИХОЛОГІЧНОЇ СТАТІ ДОШКІЛЬНИКА}

\author{
Yurii Savchenko ${ }^{1}$ \\ Lydmila Bulana ${ }^{2}$
}

DOI: https://doi.org/10.30525/978-9934-588-15-0-126

\begin{abstract}
The intense changes in the modern Ukrainian family, the current trends in its development, especially in large metropolitan areas, necessitate a rethinking and requirements clarification for preparing young people for family life that is directly related to the process of individual's psychological gender forming as man and woman. The interest in this problem is caused not only by the fact that gender is one of the most important historical, cultural and social issues, but also by the fact that the contemporary requirement of an individual approach to personality`s formation cannot be realized without taking into account the child's psychological gender. Meanwhile, the analysis of the problem of psychological gender is often reduced to finding obvious differences only at the household level fixed in the men and women's behavior, taking into account the psychological characteristics of each person, conditions and environment of his life. In addition, the formation of psychological gender is an integral feature of the individual's harmonious development. In this regard, modern psycho-pedagogical studies are increasingly attempting to consider personal's development in indissoluble unity with the person's formation of a particular gender, which determines the individual's behavior content as a man or woman, boy or girl. Analysis of psychological and pedagogical sources showed a rather intensive interest of scientists and practitioners in the problems of psychological gender ontogeny (G. Varga, V. Vasyutinsky, I. Kon, A. Paliy,
\end{abstract}

${ }^{1}$ Candidate of Psychological Sciences, Associate Professor,

Deputy Director on Scientific, Pedagogical, Social and Humanitarian Work of

Pedagogical Institute of Borys Grinchenko Kyiv University, Ukraine

${ }^{2}$ Aspirant of Institute of Human Sciences of

Borys Grinchenko Kyiv University, Ukraine

(C) Yurii Savchenko, Lydmila Bulana 
T. Repina, Yu. Savchenko, etc.); peculiarities of the psychological gender manifestation (A. Belkin, T. Govorun, D. Isaev, V. Kagan, etc.); influence of the phenomenon under study on the child's personality and individuality`s development (L. Arutyunova, D. Kolesov, O. Kononko, V. Kuzmenko, S. Kulachkivska, N. Selverova, etc.). This state of the problem under consideration is due to the increasing public attention to the individual as a unique holistic phenomenon, determining the priority direction of its study - subjective reality, individuality. In addition, the process of becoming a psychological gender affects the individual's mental health, the unity of its emotional, cognitive and behavioral manifestations. It is known that the formation of psychological gender as a personality`s integral formation occurs in the process of harmonious combination of his gender ideas, gender identity and gender-role behavior, which are embedded in preschool age and are significant at all subsequent stages of its ontogeny. Despite the importance of research into the problem of becoming a child's psychological gender, the issues of the preschool child's psychological gender development and the peculiarities of its formation in the parent-child's relationship remain underdeveloped, since it is the parent-child's relations that form an important subsystem of the whole family, which is the whole system, and can be seen as continuous, long-lasting, and mediated by age-specific child and parent's characteristics.

\section{1. Ветуп}

Інтенсивні зміни в сучасній українській сім'ї, актуальні тенденції іiі розвитку, особливо в умовах великих мегаполісів, зумовлюють потребу в переосмисленні та уточненні вимог до підготовки молоді до сімейного життя, що безпосередньо пов'язане з процесом формування психологічної статі особистості - чоловіка і жінки. Інтерес до зазначеної проблеми обумовлений не тільки тим, що становлення статі одне 3 найважливіших історико-культурних, соціальних питань, а й тим, що сучасна вимога індивідуального підходу до формування особистості не може бути реалізована без врахування психологічної статі дитини. Тим часом аналіз проблематики психологічної статі зводиться нерідко до констатації очевидних, лише на побутовому рівні фіксованих, відмінностей у поведінці чоловіків і жінок, залишаючи поза увагою психологічні особливості кожної людини, умови та середовище ії 
життєдіяльності. До того сформованість психологічної статі виступає невід'ємною рисою гармонійного розвитку особистості. У зв'язку 3 цим у сучасних психолого-педагогічних дослідженнях дедалі частіше робляться спроби розглянути особистісний розвиток у нерозривній єдності з формуванням людини певної статі, що визначає зміст поведінки індивіда як чоловіка або жінки, хлопчика або дівчинки.

Аналіз психолого-педагогічних джерел засвідчив доволі активний інтерес вчених і практиків до проблем онтогенезу психологічної статі (Г. Варга, В. Васютинський, І. Кон, А. Палій, Т. Рєпіна, Ю. Савченко й ін.); особливостей прояву психологічної статі (А. Бєлкін, Т. Говорун, Д. Ісаєв, В. Каган й ін.); впливу досліджуваного явища на розвиток особистості та індивідуальності дитини (Л. Арутюнова, Д. Колесов, О. Кононко, В. Кузьменко, С. Кулачківська, Н. Сельвєрова й ін.).

Такий стан досліджуваної проблеми обумовлений підвищенням уваги суспільства до людини як унікального, неповторного, цілісного явища, визначенням пріоритетного напрямку іiї вивчення - суб'єктивної реальності, індивідуальності. Крім того, процес становлення психологічної статі позначається на психічному здоров'ї особистості, єдності їі емоційних, когнітивних та поведінкових проявів.

Як відомо, становлення психологічної статі як інтегрального утворення особистості відбувається у процесі гармонійного поєднання іiі статевих уявлень, статевої ідентичності та статево-рольової поведінки, які закладаються в дошкільному віці й є значущими на всіх наступних етапах ії онтогенезу. Попри важливість дослідження проблеми становлення психологічної статі дитини, недостатньо розробленими залишаються питання специфіки розвитку психологічної статі дошкільника, а також особливостей іiі становлення у системі батьківсько-дитячих стосунків.

\section{2. Психологічна характеристика взаємодії дитини з батьками}

У дослідженні процесу становлення психологічної статі старшого дошкільника слід враховувати, що успішність цього процесу залежить від характеру емоційних стосунків хлопчиків і дівчаток 3 матір'ю і батьком, компетентності й престижу батьків тієї самої статі, що й дитина, а також від характеру статево-рольової взаємодії у системі батьківсько-дитячих стосунків. Важливе значення для розвитку 
статевої самосвідомості дошкільників має їх взаємодія з батьками, котрі навчають дітей співіснувати відповідно до загальноприйнятих суспільних стереотипів.

Через спілкування дорослих 3 дітьми відбувається виховання як цілеспрямований розвиток дитячої особистості. Одним із важливих завдань цього $є$ налагодження добрих інтерперсональних відносин 3 особами своєї і протилежної статі.

Неодмінними умовами контакту дитини і дорослого виступають постійність спілкування з одними і тими самими людьми та тривалість цих взаємин у сім'ї.

В наш час багато досліджень присвячено вивченню різних аспектів впливу сімейних стосунків на особистісний розвиток дитини. Загальновизнаним $є$ факт унікальності внеску сім’ї в емоційно-моральний розвиток особистості.

У зв'язку з цим особливо актуальними стають положення про становлення психологічної статі дитини у процесі батьківсько-дитячої взаємодії. Слід також враховувати, що ефективність процесу становлення статевої ідентифікації детермінується, як зазначалося, відповідною взаємодією батьків 3 дітьми, яка спрямовує розуміння хлопчиками $\mathrm{i}$ дівчатками суспільних статевих стереотипів; активним наслідуванням дітьми статево-рольової поведінки, що відбувається під час засвоєння ними психологічних рис своєї статі і проявляється у зовнішніх формах поведінки дошкільників. Тим часом система сімейних стосунків по-різному розглядається в сучасній психологічній літературі. Один із провідних підходів до їх вивчення полягає у ролі батьківсько-дитячих стосунків, прабатьківської сім'ї, братів і сестер, чисельного складу сім'ї у формуванні психологічної статі дитини. Стиль батьківського спілкування репродуктивний, багато в чому він задається сімейними традиціями, що дає підстави говорити про безумовний вплив батьків; загальновизнано, що матері відтворюють стиль виховання, властивий їх власному дитинству, часто повторюючи стиль своєї матері.

Багато вчених наголошують на ролі братів і сестер у становленні психологічної статі дитини. На думку дослідників, брат суттєво впливає на ідентифікацію хлопчика завдяки сумарному збільшенню в сім’ї осіб тієї самої статі. У дівчаток наявність сестри не позначається на ідентифікації подібним чином - можливо, через більшу вираженість 
ідентифікації з матір'ю. Разом з тим дівчатка більш чутливі, порівняно 3 хлопчиками, до конфліктних стосунків між батьками. За наявності останніх дівчатка рідше ідентифікують себе з матір'ю [1; 4].

Слід також вказати на значення чисельного складу сім’ї у становленні психологічної статі дитини. На формування особистості дитини та іiі статі - у разі збільшення чисельного складу сім’ї завдяки сіблінгам впливатимуть ті самі групові процеси, що й у дитячій ігровій групі: прискорюються вироблення комунікативних навичок, розвиток емпатії тощо.

Охарактеризовані вище особливості сімейного впливу відображають об'єктивні детермінанти особливостей формування особистості дитини. Однак головний інтерес викликають - 3 точки зору практичних завдань психологічної допомоги сім'ї - батьківське ставлення і його вплив на процеси становлення психологічної статі у дітей. Батьківське ставлення - означає виховний процес у сім’і: це синонім таких термінів, як батьківське виховання, батьківські відносини, тип виховання.

Отже, батьківсько-дитячі стосунки становлять найважливішу підсистему сімейного виховання і розглядаються як пролонговані, довготривалі відносини дитини і батьків, опосередковані їх психологічними особливостями. На відміну від інших різновидів міжособистісних відносин дитячо-батьківські стосунки відзначаються високим рівнем їх значущості для обох сторін.

Розглядаючи батьківсько-дитячі стосунки як пріоритетну детермінанту психічного розвитку і процесу соціалізації дошкільників, подамо основні психологічні характеристики взаємодії дитини з батьками:

- характер емоційного зв'язку (з боку батьків - це емоційне прийняття дитини, тобто батьківська любов, з боку дитини - емоційне ставлення до батьків, дитина відчуває прихильність до батьків);

- наявність стійких мотивів у сімейному вихованні;

- включеність батьків у процес піклування про дитину;

- забезпечення автономії дитини під час розв'язання проблемних та конфліктних ситуацій;

- соціальний контроль (додержання прав, обов'язків, вимог, заборон; а також визначення їх змісту, кількості, способів контролю, санкцій (заохочення і підкріплення), батьківський моніторинг);

- стійкість і послідовність (чи суперечливість) сімейного виховання. 
Перелічені психологічні характеристики взаємодії дитини з батьками справляють вплив на інтегровані показники дитячо-батьківських стосунків:

- батьківську позицію, яка визначає характер емоційного прийняття дитини, мотиви та цінності виховання, наявний образ дитини й усвідомлення самого себе як батька, модель батьківської рольової поведінки;

- тип сімейного виховання, яким задаються параметри емоційних стосунків, стиль спілкування та взаємодії, ступінь задоволення потреб дитини, особливості батьківського контролю та послідовність його реалізації;

- образ батьків як вихователів і образ системи сімейного виховання у дитини, що визначає мету досягнення узгодженості й співпраці у розв'язанні завдань спільної діяльності і забезпечує потрібні для гармонійного розвитку дитини умови.

Таким чином, роль і вплив батьків на становлення психологічної статі змінюються під впливом зміни виховної парадигми. Ця зміна відбувається у процесі переходу від суб'єкт-об'єктної до суб'єкт-суб'єктної взаємодії між батьками і дитиною. Такі стосунки характеризуються проявом гуманістичного настановлення у сімейному вихованні, що сприяє розвитку суб'єктної взаємодії у сім’ї і встановленню статусу дитини як рівноправного учасника батьківсько-дитячих стосунків.

Для більш повної характеристики психологічної статі проаналізуємо процес її зародження. На думку багатьох дослідників, розвиток дитини до двох-трьох років - це період раннього природного симбіозу між нею і матір'ю, період первинної статевої ідентифікації для дітей обох статей. Це приводить до того, що згодом перед хлопчиками постає проблема переключення з ідентифікації з матір'ю на опанування чоловічої ролі. Цей процес може ускладнюватись через певну незрозумілість моделі батька за таких умов: батько менше часу проводить 3 дітьми, ніж мати; мати намагається утримати симбіотичні стосунки з дитиною за межами природного симбіозу.

У своїх дослідженнях дослідники стверджують, що у дитини до п'яти років виражена потреба в емоційному контакті та любові з батьком протилежної статі. Любов і симпатія поширюються не тільки на батьків, а й на інших представників тієї самої статі, включаючи одно- 
літків. Ставлення до дітей неоднакової статі є різним, але здебільшого неусвідомлюваним [3].

Зазначимо, що відмінності у статевій соціалізації хлопчиків і дівчаток тривалий час вивчалися без врахування тих впливів, які здійснює кожен 3 батьків. На сучасному етапі думки більшості дослідників досить одностайні: домінуючим чинником у процесі виховання $є$ особистість батьків. Дослідження материнської депривації та неблагополучних сімей дали змогу визначити пріоритетний вплив матері на розвиток психіки дитини. Роль матері не зводиться лише до функцій первинної соціалізації, сенсорної стимуляції та емоційної підтримки дитини. Наголошується на особливо значущому внеску матері у навчання дитини мові і спілкуванню; в озброєння дошкільника етичними нормами соціальної поведінки як проекції власного життєвого досвіду.

На думку Т. Репіної, еталон матері та уявлення про жінку відіграють значну роль у подальшому виборі чоловіком дружини та його стосунках з нею: можливо, такий процес відбувається завдяки особливій значущості матері для хлопчика. В дослідженнях ученого йдеться також про те, що батько здійснює більш слабкий вплив на формування еталонів майбутнього чоловіка у доньки, хоча 3 приводу цього питання існують й інші погляди. У багатьох працях підкреслюється важливість «перехресного» впливу батьків на дітей: батька на доньку, а матері на сина. Крім того, тривалий час вважалося, що батько - на відміну від матері - не впливає на статеву соціалізацію дітей. Але останнім часом вчені з'ясували значення образу батька для психічного розвитку хлопчиків. У разі відсутності такого образу дитині не вистачає того, в чому виявляються особливості чоловічої психіки, що призводить до зниження соціальної активності та появи інфантилізму [4].

Так, на відміну від дітей, які мали батька або втратили його у старшому дошкільному віці, у дітей 4-5 років відсутність батька впливала на порушення їх сексуально-рольової орієнтації, виникнення конфліктів з однолітками у спільних рольових іграх. У результаті дійшли висновку, що образ батька як у хлопчиків, так і у дівчаток сприяє формуванню більш адекватної «Я-концепції» дитини і спрямовує розв'язання завдань когнітивного характеру i міжособистісного спілкування. В останні роки з'явилася загроза зниження батьківського авторитету та загальної фемінізації сімейних стосунків. Учених також непокоїть 
загальна фемінізація сімейного виховання, яка негативно впливає на гармонізацію особистісного розвитку дітей.

\section{3. Вплив батька і матері на розвиток психологічної статі дитини}

Відомо, що для формування адекватних моделей материнської та батьківської поведінки в дошкільному віці особливе значення має досвід взаємин з обома батьками. Тому для повноцінного становлення дитячої особистості важливими є статево-рольові стосунки між чоловіком і жінкою, матір'ю і батьком, що їх наслідують діти. Результати досліджень впливу особистості батьків підтверджують думку про те, що їх стать відіграє певну роль у становленні психологічної статі дітей. Диференціація ставлення матерів щодо дітей різної статі бере свій початок у вроджених задатках і спрямовується їх соціальною поведінкою.

У своїх дослідженнях Т. Репіна вказує на наявність підвищеної активності вихователя щодо дитини своєї статі: жінки більш прихильні до дівчаток і підкріплюють їх поведінку «відповідно» до бажаної статевої ідентифікації. Дослідниця показала, що матері і батьки виконують різні функції у статево-рольовій соціалізації дітей: кожен 3 батьків у своїх стосунках 3 дітьми схильний більше зважати на особу своєї статі, ніж дотримуватися позиції дитини іншої статі. Тобто мати при спілкуванні з донькою орієнтується на їі психологічні властивості, а батько намагається реагувати на поведінку доньки, схиляючись до позиційних аспектів [4].

Тим часом Д. Ісаєв відзначає, що розвиток у дитини статево-рольових стереотипів пов'язаний більше з соціалізуючим впливом батьків протилежної статі, ніж із впливом одного з батьків спільної статі. Тобто батько іншої статі більшою мірою підкріплює обумовлену культурою стереотипну поведінку дитини [2].

Останнім часом поширюється думка про те, що на рівні усвідомлення батьки не диференціюють своє ставлення до дітей відповідно до статі: більше того, батьки зазвичай змінюють типи ставлення до дітей, що призводить до «фемінізації» хлопчиків та «маскулінізації» дівчаток. Причиною цього, ймовірно, $є$ те, що батьки не враховують психологічної специфіки статі дитини й опосередковано посилюють цю тенденцію, не розуміючи принципів емансипації. 3 другого боку, чітке настановлення на дотримання традиційних статево-рольових 
відмінностей, які не відповідають зміненим умовам, може бути патогенним фактором, під впливом якого у людей виробляються однобічні та нереалістичні критерії маскулінності/фемінінності.

У численних дослідженнях психологів і педагогів наголошується на виховній значущості внутрішньосімейних стосунків, які складаються 3 двох сімейних підсистем - подружньої та батьківської. Як правило, стосунки у сім'ї визначаються характером подружніх стосунків. На жаль, наявних досліджень, де встановлюється характер спілкування подружжя та його вплив на становлення психологічної статі дітей, недостатньо для того, щоб розробити чітку типологію.

Особливо істотно позначається на становленні психологічної статі старших дошкільників виховний вплив: це діяння дорослого у спілкуванні з дітьми, яке змінює суб'єктивні характеристики дитини потреби, настановлення, відносини, здібності, поведінку тощо.

Важливо додати, що батьківське ставлення найбільш вивчений напрямок дитячо-батьківських стосунків. У клінічній літературі подано достатньо широку феноменологію батьківського ставлення, а також показано наслідки формування індивідуальних особливостей дитини в межах нормальної або девіантної поведінки. Виокремленні типи батьківського виховання, як правило, характеризують несприятливі виховні впливи. Більш активно розробляється ця проблема у сфері клініко-психологічних досліджень.

Так, у зарубіжній та вітчизняній літературі виокремлено несприятливі чинники виховання, що спричиняють розвиток у дитини негативних особистісних якостей. Ці чинники розрізняються на підставі типу виховання та видів батьківського контролю. Серед патогенних типів виховання, які негативно впливають на процес становлення психологічної статі дитини, можна виокремити такі: низьку згуртованість і неузгодженість намірів і дій членів сім'ї з приводу виховання. На думку Д. Ісаєва і В. Кагана, для дитини власне «Я»- це похідне від сім’і, тому важливі узгодженість і спільність думок батьків на процес виховання дитини, на прояви іiї статі, а також об'єктивне співвіднесення статевих ролей батьків та їх характерів. Крім того, спроби одного з батьків емоційно наблизити до себе дитину на шкоду стосункам з іншим можуть мати наслідком зменшення інтенсивності процесу ідентифікації, в тому числі статевої [2; 3]. 
Виховання за типом «відторгнення» - це неприйняття, ворожість, негативне ставлення до дитини, жорсткий контроль, регламентація iii життя, нав'язування їй «правильного» типу поведінки. Дуже часто відторгнення супроводжується інфантилізацією та індивідуалізацією дитини. Жорсткий контроль 3 боку батьків здійснюється насамперед за допомогою системи покарань. Більшість батьків переконані у потребі прищеплювати дитині такі цінності, як повага до авторитету, працелюбство, необхідність збереження існуючого порядку.

Результатом ворожого ставлення до дитини можуть стати складнощі у соціальній адаптації, нерішучість у спілкуванні з однолітками, агресивність, схильність до суперечок, соціальна відсталість. Зазначений тип виховання характеризується підвищеною авторитарністю батьків внаслідок відторгнення дитини та частих покарань. На думку багатьох вчених, особливо негативним у стосунках батьків 3 дітьми $€$ покарання, до того встановлено статеву асиметрію щодо покарань дітей. Статево-рольове виховання будується на приниженні неіснуючої статево-рольової поведінки, причому заборони більш-менш i у більш жорсткій формі стосуються хлопчиків, ніж дівчаток. У системі цих настановлень «бути хлопчиком» означає небажання гратися у ляльки, займатися традиційно «жіночими» видами діяльності, але прагнення допомагати батьку, навіть долаючи для цього великі перепони. «Бути дівчинкою» означає можливість грати в усі ігри, які подобаються, допомагати не тільки у жіночій, а й у чоловічій праці.

Гіперсоціалізуюче виховання, або симбіотичний тип батьківського ставлення, означає центрацію батьків на вихованні: вони приділяють дитині дуже багато часу, сил та уваги. Виділяють два основних типи гіперпротекції. При домінуючій (авторитарно-симбіотичній) гіперопіці поєднуються батьківська любов і обмеженість. Наслідками подібного виховання можуть стати такі якості особистості дитини, як покірність, залежність, мінімум агресії, максимальна поступливість, некреативність.

При гіперопіці (симбіотичній) батьки прагнуть до максимального задоволення потреб дитини, потурають усім її бажанням. Наслідком гіперпротекції стають складнощі в адаптації дитини в соціальному середовищі, поява таких характерологічних особливостей, як впертість, недовіра, хвороблива образливість та самолюбство. 
Найчастіше схильність до симбіотичних стосунків властива матерям. Тенденцію до симбіотичних стосунків з боку батьків можна охарактеризувати у змістовому плані таким чином: батьки відчувають себе 3 дитиною неподільним цілим, намагаються задовольнити всі іiі потреби, позбавити від проблем та негараздів життя.

Батьки постійно хвилюються за дитину, оскільки вона здається їм маленькою та беззахисною. Тривога батьків зростає, коли дитина починає за певних обставин віддалятися від них, оскільки батьки в жодному разі не нададуть їй самостійності з власної волі.

Слід зазначити, що симбіотичні стосунки у діаді «мати - дитина» закономірні на етапі немовляти у ранньому віці. Але по закінченню кризи трьох років дитина має психологічно відокремитися від матері, інакше їі психічний розвиток відбуватиметься неадекватно.

«Авторитарна гіперсоціалізація» - компонент, який відображає форму та зміст контролю за поведінкою дитини. У стосунках батьків 3 дитиною чітко простежується авторитаризм. Батьки вимагають від дитини підкорення та дисципліни, намагаючись нав'язати їй власну волю. За будь-який прояв свавілля дитину суворо карають. До того батьки слідкують за соціальними досягненнями дитини, іiі індивідуальними особливостями, звичками, думками, почуттями.

Наслідки авторитарної гіперсоціалізації є дуже несприятливими для психічного розвитку дитини.

Ставлення до дитини як до «маленького невдахи» відображає особливості сприймання та розуміння іiі батьками. Мають місце намагання батьків інфантилізувати дитину, зробити ії індивідуально та соціально недієздатною. Батьки вважають дитину молодшою, ніж це є наспрвді. Інтереси, потяги, думки, почуття дитини здаються батькам занадто дитячими. Дитину розглядають як неспроможну активно засвоювати досвід і відкриту для негативних впливів. Батьки не довіряють власній дитині, скаржаться на її недовершеність. У зв'язку з цим батьки намагаються звільнити дитину від труднощів життя і суворо контролювати іiі дії. Вони обирають і пропонують дитині тільки таку діяльність, яка, на їх думку, буде найбільш корисною для неї.

В умовах подібних стосунків дитина живе 3 постійним відчуттям невідповідності запитам батьків і перебуває під тиском таких настанов: «Я поганий»; «Я неспроможний»; «Я не зможу, не зумію». Вона 
робить все, аби оточуючі зрозуміли ії нікчемність. У зв'язку з цим дослідники зазначають, що подібна ситуація дуже несприятлива для підростаючої людини - вона не може самореалізуватися в діяльності, оскільки запропонована їй діяльність не відповідає ії особистісним смислам. Як наслідок ця діяльність не може сприяти розвитку саме цієї дитини, і вона сама намагатиметься знайти будь-який спосіб захисту. «Заглибитись у саму себе, стати апатичною, пасивною краще, ніж нічого не робити, тоді нічого не зіпсуєш. Або, навпаки, вона намагатиметься отримати визнання, привернути увагу, а оскільки з добрими справами у неї нічого не виходить, відкриється шлях до злих намірів та примх. А іноді невдаха теж намагається стати переможцем, а оскільки в реальних змаганнях він не переможе, то шукає інші шляхи, готовий на підкуп та махінації».

Психологи виокремлюють гіперпротекцію з боку батьків дитини. Цей тип неправильного виховання характеризується недостатньою опікою та контролем за поведінкою дитини, він може набувати «прихованих» або «потуральник» форм.

Дослідники виділяють також непослідовний тип сімейного виховання, коли батьки різко змінюють стиль, прийоми впливу; суперечливе виховання, коли члени сім'ї демонструють несумісні виховні підходи та вимоги. Ці типи виховання часто призводять до патогенних наслідків, зумовлених підвищеною стимуляцією можливостей дітей, частим використанням покарань, погроз, заборон. На думку Д. Ісаєва, В. Кагана, недооцінка маскулінності/фемінінності призводить до бажання стимулювати маскулінність хлопчиків у процесі створення надвимог, які є складними для дитини і знижують цінність та силу іiі «Я». Тим самим батьки сприяють процесу фемінізації хлопчика. Такий неадекватний підхід до виховання дитини дуже часто супроводжується розвитком у неї почуття меншовартості, пов'язаного зі статтю, деякою «схибленістю», почуттям провини за невміння бути іншим [2; 3].

Найбільш сприятливим типом сімейного виховання вважається «прийняття дитини і любов до неї», співпраця з дитиною, демократичний стиль батьківського виховання. У сім'ях, що послуговуються цим типом виховання, батьки здатні вчасно прийти на допомогу дитині, але не нав'язливі й вірять в успіх їі самостійної діяльності; при цьому діти включені в обговорення сімейних проблем; батьки схвалюють неза- 
лежну поведінку сина або доньки, приймають їх індивідуальність, враховують інтереси, схильності.

Такий тип виховання, на думку Д. Ісаєва і Н. Александрової, сприяє засвоєнню дитиною визначених вимог до тієї чи іншої статі. Вона ідентифікує себе з матір'ю або батьком. Разом з тим батьки у подібних сім'ях відзначаються локальним авторитаризмом: вимагають зовнішніх досягнень і здійснюють контроль лише у сфері досягнень [2; 3].

\section{4. Батьківські позиції до розвитку психологічної статі дошкільника}

На підставі аналізу джерел нами визначено три основних чинники батьківської позиції, які сприяють розвитку психологічної статі дитини і проявляються у ставленні батьків до неї:

1) адекватність - чинник, найбільш близький до об'єктивної оцінки психічних та характерологічних особливостей власної дитини, що дає змогу побудувати виховання, спираючись на цю оцінку;

2) динамічність - здатність змінювати методи і форми спілкування і впливу на дитину відповідно до зміни ситуацій та умов життя у сім’'і;

3) прогностичність - спрямованість виховних вимог у майбутнє, орієнтація на ті вимоги, які ставитиме перед дитиною ії подальше життя [4].

Адекватність батьківського ставлення пов'язана з такими феноменами, як приписування дитині батьками тих чи інших якостей - ступінь створення цих якостей, викривлене сприймання образу дитини. Батьки досить часто недиференціюють своє ставлення до дітей згідно зі статтю: більше того, вони змінюють типи ставлення до дітей, що призводить до фемінізації хлопчиків і маскулінізації дівчаток.

Іноді незадоволення батьків щодо реальної статі дитини може призводити до нав'язування їй стереотипів і мотивацій поведінки іншої статі. Непоодинокими є випадки, коли відторгнення реальної статі або надмірні вимоги до дитини - найчастіше до іiі мужності - не викликали статево-рольових порушень, але задовольнялися через негативні прояви поведінки.

Дані психологічних досліджень свідчать про наявність такої актуальної проблеми, як фемінізація хлопчиків. Це пов'язано насамперед 3 тим, що хлопчики знаходяться під сильним жіночим впливом у сім'ї та школі і в результаті наслідують жіночі зразки поведінки. 
Дослідження показали: батьки, котрі бажають мати дівчинку, несвідомо переносять на хлопчика весь комплекс розвинених у них до його народження почуттів, пов'язаних з вихованням дівчинки, або ж батьки, котрі хотіли мати тільки хлопчика, ставлять йому дуже жорсткі вимоги, часто доводячи дитину до неврозу, а потім змінюють полярні настановлення. Найсуттєвіший чинник розвитку у хлопчиків не властивої їх статі поведінки - недостатня увага і відсутність реальних чоловічих зразків поведінки.

Це зумовлює актуальність проблеми батька як вихователя: адже, на думку вчених, у сучасному місті традиційні риси батька помітно слабшають під впливом таких явищ, як жіноче рівноправ'я, тісний сімейний побут, відсутність жорсткого поділу праці. Все це породжує певні соціально-психологічні проблеми та скарги на зниження батьківського авторитету, загальну фемінізацію сімейних стосунків. Недостатність батьківського впливу, своєрідна чоловіча депривація несприятливо позначаються на відносинах у батьківській сім’ї - як у сфері батьківських стосунків, так і у сфері виховання. Ускладнює відносини і надмірність материнського та жіночого впливу у прабатьківських сім'ях.

Ефективність адекватного батьківського ставлення залежить від яскравості та послідовності батьківських уявлень про типи поведінки дітей різної статі. Чим менш зрозуміліший батькам образ соціально-статевої поведінки дитини, тим складніше їй пристосовуватися, тим більше у неї шансів зірватися при неможливості задовольнити соціальні очікування оточуючих або у разі появи почуття «недостатності».

Крім того, становлення психологічної статі дитини починається 3 опанування нею зразків поведінки батьків, їх стосунків та переваг; сприйняття і засвоєння дитиною статевих ролей залежить від того, чи демонструють їх батьки. Наприклад, іноді у сім'ї складається патогенна ситуація (причому значення іï для хлопчиків та дівчаток неоднакове), коли батько перейнятий почуттям тривоги, надмірно ніжний, всепрощаючий і енергійна, вимоглива, надпринципова мати, втомлена побутом. Досить часто відсутність зрозумілих стереотипів маскулінності/фемінінності відображається у вадах або надмірній емоційності тактильного контакту щодо дітей (якісна неадекватність статі дитини і вихователя).

Динамічність батьківського ставлення означає ступінь їі рухливості як у сприйманні дитини, так і у взаємодії з нею. 
На думку В. Кагана, суворе ставлення батьків до наслідування традиційних статево-рольових відмінностей у дітей, які не відповідають новим соціальним умовам, може стати патогенним чинником, зумовлюючи появу у людей однобоких та нереалістичних критеріїв маскулінності/фемінінності.

Третьою властивістю конструктивного батьківського ставлення $є$ прогностичність, що означає здатність батьків до екстрапуляції, передбачення перспектив подальшого розвитку дитини і їх спроможність встановити з нею взаємодію з урахуванням цього передбачення.

На думку ряду вчених, головним у статевому вихованні слід вважати опанування дітьми загальноприйнятих соціальних ролей. Ще до того, як діти усвідомлять свою статеву належність, батьки - через наочний приклад, інструкції, відповідні ситуації - мають створити образ хлопчика або дівчинки. Вони повинні забезпечити умови для становлення статевої ролі дитини шляхом відмінностей в одязі, називання якостей відповідно до статі, підбору ігор та іграшок, вироблення певних навичок [1;3].

У свою чергу, ті вчені, котрі розглядають проблематику становлення психологічної статі з точки зору підготовки дитини до майбутнього життя, радять батькам правильно оцінювати і прогнозувати тенденцію розвитку статевих соціальних ролей. Вчені зазначають, що статевий поділ праці перестає бути суворим у наш час, коли кількість суто чоловічих або жіночих занять різко зменшилась, спільне навчання та трудова діяльність сприяють нівелюванню традиційних відмінностей у нормах поведінки, руйнуються традиційні культурні стереотипи, спостерігається неконкретність та суперечливість ідеалів маскулінності/фемінінності.

Відповідно до стилів і властивостей сімейного виховання і їх впливу на становлення психологічної статі дитини старшого дошкільного віку визначено сприятливі умови для розвитку особистості дитини.

Перша умова - це впевненість дитини у батьківській любові. Першим та головним завданням батьків є створення у дитини впевненості в тому, що ії люблять і про неї дбають. Ніколи, в жодному разі у дитини не має виникнути сумнів у батьківській любові. Адже тільки за умови впевненості дитини у батьківській любові і можливе правильне формування психологічного світу, лише на основі любові можна виховати моральну поведінку і тільки любов здатна навчити любові. 
Друга умова - діалогічне спілкування. Дитина навіть у найбільш ранньому віці має стати не об'єктом виховних впливів, а союзником у загальному сімейному житті, у відомому сенсі його будівничим і творцем. Основними характеристиками діалогічного спілкування виступають емоційна та особистісна відкритість партнерів зі спілкування, психологічна налаштованість на сприймання актуального стану один одного, безоцінність, довірливість та щирість у вираженні почуттів та станів. Таке спілкування характеризується рівністю психологічних позицій учасників, активністю сторін, коли не тільки виникають впливи, а й вони самі однаковою мірою впливають на іншого, взаємним проникненням партнерів у світ почуттів і переживань. На думку Д. Ісаєва і В. Кагана, вироблення настановлень на маскулінність/ фемінінність може бути успішним не тоді, коли дорослий (активний суб'єкт) «ліпить» 3 дитини (пасивного суб' єкта) хлопчика або дівчинку i, зрозуміло, не тоді, коли дорослий просто викликає відповідну реакцію у дитини, а саме тоді, коли маскулінність/фемінінність дорослого і дитини взаємодіють і обумовлюють одне одного. Отже, у підгрунті процесу становлення психологічної статі лежить не стільки ідентифікація дитини з батьками, скільки їх активна взаємодія [2; 3].

Третя умова - прийняття права дитини на притаманну їй індивідуальність, неподібність до інших, у тому числі неподібність до батьків. На нашу думку, це твердження треба розглядати в аспекті розуміння статевої належності особистості як важливого чинника індивідуальності. Проблема підготовленості підростаючого покоління до виконання соціальних ролей в майбутній сім'ї - ролей чоловіка і жінки, батька i матері - може бути успішно вирішена, як стверджують Л. Арутюнова і Т. Рєпіна, тільки у диференційованому підході до виховання хлопчиків і дівчаток. Диференційований підхід передбачає знання про статеві психологічні відмінності. Експериментальні дані у зарубіжній психології щодо цього численні, але дуже суперечливі [4].

На думку Д. Ісаєва, у вихованні хлопчиків і дівчаток насамперед потрібно враховувати природні схильності, не заважати їх саморозвитку. Наприклад, у дівчаток засвоєння і формування відповідних якостей буде успішнішим, якщо їм створюватимуть сприятливі умови з урахуванням потреби у більш високому ступені тренування та научіння [2]. 
Заглядаючи у далеке майбутнє, американські та західноєвропейські психологи зазначають, що чоловічі та жіночі соціальні ролі будуть однаковими. Ряд вчених ставить питання про цілеспрямований вплив на статеву культуру з метою поліпшення відповідності вимог новим історичним умовам.

\section{5. Висновки}

Таким чином, батьківсько-дитячі стосунки утворюють важливу підсистему стосунків у сім'ї, що є цілісною системою, і можуть розглядатися як безперервні, тривалі та опосередковані віковими особливостями дитини і батьків стосунки. Роль образу батьків і дитини у батьківсько-дитячих стосунках полягає в орієнтуванні у цій системі стосунків з метою досягнення узгодженості та співпраці у розв'язанні завдань спільної діяльності і забезпечення необхідних умов гармонійного розвитку дитини.

\section{Список літератури:}

1. Эйдемиллер Э.Г. Семейная психотерапия / Э.Г. Эйдемиллер, В.В. Юстицкий. - Л.: Медицина, 1989. - 192 с.

2. Исаев Д.Н. Психогигиена пола у детей : руководство для врачей / Д.Н. Исаев, В.Е. Каган. - Л.: Медицина, 1986. - 336 с.

3. Каган В.Е. Воспитателю о сексологии / Виктор Ефимович Каган. М.: Педагогика, 1991. - $256 \mathrm{c.}$

4. Репина Т.А. Проблема полоролевой социализации детей / Татьяна Александровна Репина. - М.: Изд-во Моск. психолого-социального института. - М., 2004. -288 c.

\section{References:}

1. Eydemiller E.G. (1989). Semeynaya psikhoterapiya [Family therapy]. Leningrad: Meditsina. (in Russian)

2. Isaev D.N. (1986). Psikhogigiena pola u detey : rukovodstvo dlya vrachey [Sexual hygiene in children: a guide for doctors]. Leningrad: Meditsina. (in Russian)

3. Kagan V.E. (1991). Vospitatelyu o seksologii [Educator about sexology].

4. Moscow: Pedagogika. (in Russian)

5. Repina T.A. (2004). Problema polorolevoy sotsializatsii [The problem of sex-role socialization of children] Moscow: Izd-vo Mosk. psikhologo-sotsial'nogo instituta. (in Russian) 